\title{
Budesonide-Cyclodextrin in Hydrogel System: Impact of Quaternary Surfactant on in vitro-in vivo Assessment of Mucosal Drug Delivery
}

\author{
SUNIL PATTANAIK, SOUVIK NANDI, RUDRA NARAYANA SAHOO, ASHIRBAD NANDA, \\ RAKESH SWAIN, SHUBHASHREE DAS, SUBRATA MALLICK* \\ School of Pharmaceutical Sciences, Siksha 'O' Anusandhan (Deemed to be University), Khandagiri, Bhubaneswar, Odisha, India, \\ 751003
}

Abstract: Budesonide, a glucocorticosteroid is generally used to treat chronic inflammation and asthma. Hepatic first-pass metabolism and poor solubility are the major causes of its limited oral bioavailability. Present work was undertaken for the preparation of hydrogel film formulation with cyclodextrin complexation of budesonide containing quaternary surfactant for possible enhancement of mucosal permeation. FTIR study confirmed drug-polymer hydrogen bonding. Almost complete amorphization of the drug was pronounced by SEM, DSC and XRD studies. The film containing benzalkonium and hydroxypropyl beta-cyclodextrin exhibited in vitro dissolution and mucosal permeation to the highest extent of 87.2 and $95.8 \%$ respectively in contrast to the others. Film formed hydrogel in aqueous mucin and enhanced the mucosal tissue residence time due to the mucoadhesive nature of the polymer. Acute inflammation in the rabbit eye was controlled within 3 by applying the film in the cul-de-sac. The presence of cyclodextrin and quaternary surfactant brought about significantly improved drug release and mucosal permeation compared to their absence in the HPMC film. Hydrogel formed in aqueous mucin enhanced the mucosal residence time and controlled acute inflammation in the rabbit eye within $3 \mathrm{~h}$ after topical application.

Keywords: Budesonide, cyclodextrin inclusion, mucosal delivery, ocular anti-inflammation.

\section{Introduction}

Budesonide, a highly potent glucocorticosteroid is used to control asthma by decreasing swelling and irritation in air pathways for easier breathing. It is also used to treat inflammatory bowel disease (IBD), ulcerative colitis (UC), and Chron's disease (CD) [1]. It is available in the market as dry powder inhaler (DPI), tablet, and capsule formulations. According to the biopharmaceutical classification system (BCS) the drug is having high permeability and low solubility, with a $\log \mathrm{P}$ of 3.2. The oral bioavailability of budesonide is highly affected due to its poor dissolution and high hepatic first-pass metabolism (11\%). Acid hydrolysis and enzymatic degradation in the GI tract affect the absorption process after oral administration. Budesonide also shows low inhalation bioavailability of $6 \%$ with a very short elimination half-life of 2-3 h [2]. Fluidization and dispersion characteristics may be affected due to problems like upper airway deposition associated with budesonide DPI [3].

Transmucosal routes like ocular, buccal, nasal, rectal, vaginal give more discrete advantages for the administration of a drug over other non-parenteral routes. These mucosal routes also offer many times greater permeability rather than of skin [4]. Drug delivery through buccal route leads to absorption to the systemic circulation effectively bypassing the first-pass metabolism with minimal fluctuations in plasma concentration [5]. Buccal mucosal tissue is highly vascularised with blood vessels. Mucin concentration in the buccal mucosa is high for facilitating more effective mucoadhesion compared to inhalational therapy and many other mucosal deliveries [6]. Moreover, buccal tissue recovery is quicker than other delivery routes and could be appropriately explored for better drug delivery [7].

$\overline{\text { *email: profsmallick@gmail.com }}$ 
Nowadays hydrophilic vehicles play a great role in incorporating various kinds of drugs in mucosal delivery. Hydrogels as the semisolid vehicle can also be adapted easily in sustained and controlled release and thus minimizing the side effect and toxicity [8-12]. Gaikwad et al have developed an enteric-coated self nano emulsifying capsule formulation for colonic delivery of budesonide $[13,14]$. The main limitations associated with these types of delivery systems are drug loading efficiency and bulkiness of the final volume of the formulation.

Inclusion agents are used to achieve better bioavailability and dissolution due to improved physicochemical stability and increased solubility [15-17]. Cyclodextrins, a non-toxic cyclic oligosaccharide has particularly drawn attention for improving the solubility and stability of drugs [18]. Cyclodextrin complexation increased the solubility and stability of lansoprazole [19]. The use of cetrimide and hydroxypropyl beta cyclodextrin independently improved the solubility of valdecoxib [20]. Oral pediatric formulation of budesonide was prepared by inclusion complexation using cyclodextrin for increased bioavailability [6]. Transbuccal diffusion of omeprazole was increased in the presence of cyclodextrins [21]. Presence of surfactants also in the delivery system is very much promising in improving mucosal permeation. Transmucosal permeation of fluorescein isothiocyanate dextran has been improved through cornea by incorporating benzalkonium chloride in the solution [22]. Another cationic surfactant, cetrimide was also found to increase the buccomucosal permeation of peptides and proteins [23].

The solubility of a surfactant can be increased by forming an inclusion complex with cyclodextrin [24]. Critical micelle concentration of surfactants increases markedly in the presence of cyclodextrin [25]. The impact of quaternary surfactants and cyclodextrin in combination on mucosal permeation of budesonide has probably not been reported yet and could be the potential for significant improvement of bioavailability of the drug. In our study, hydrogel film has been prepared with cyclodextrin complexation of budesonide containing quaternary surfactant for possible enhancement of mucosal permeation. Film formulation was chosen because of its better patient compliance, ease of application, and other advantages like transport and storage [26]. Solvent casting method was employed for the preparation of budesonide-in-HPMC films using $\beta$-cyclodextrin or HP- $\beta$-cyclodextrin as an inclusion agent. Benzalkonium chloride (BZK) or cetrimide (CET) was also used as quaternary surfactants in combination with inclusion agent for possible enhancement of transmucosal permeation of budesonide. Budesonide films were tested for ex vivo buccal mucosal tissue permeation. In vivo anti-inflammatory activity has also been examined after topical application of film on carrageenan induced rabbit eye model $[27,28]$. The utility of ex vivo permeation (using mucosal biomembrane) was demonstrated to predict the ability of budesonide in vivo (in life system) performance.

\section{Materials and methods}

\subsection{Materials}

Budesonide was obtained from Cipla Laboratories (Goa, India) as a gift sample. HPMC K 15M and Cetyl Trimethyl Ammonium (cetrimide) were procured from Burgoyne Burbidges \& co. Laboratories (Mumbai, India). Triethanolamine and benzalkonium chloride (50\% solution) were purchased from SRL laboratories and MERCK laboratories India respectively. Beta cyclodextrin and hydroxypropyl beta-cyclodextrin were obtained from Dr. Reddy's Laboratories (Hyderabad, India) as gift samples. Carrageenan was purchased from TCI Laboratories Pvt. Ltd. Japan.

\subsection{Preparation of budesonide film}

HPMC K $15 \mathrm{M}$ was taken in a $100 \mathrm{~mL}$ beaker and $40 \mathrm{~mL}$ of distilled water was added and left for swelling at $2-8{ }^{\circ} \mathrm{C}$ for $24 \mathrm{~h}$. $\beta$-cyclodextrin and HP- $\beta$-cyclodextrin, triethanolamine, and surfactants were incorporated into the viscous polymer solution with continuous stirring. Budesonide in $10 \mathrm{~mL}$ of methanol solution was added to the mixture and stirring continued for 2-3 h until a fully transparent solution was obtained. The drug-polymer solution was then poured on Tarson Petri dish and left to dry at $40-50{ }^{\circ} \mathrm{C}$ for $36-48 \mathrm{~h}$. Complete drying was assured when a constant weight was achieved of the 
prepared film. Films were separated from the Petri dish and packed in the zip lock Tarson pouch and preserved in an airtight container until further studies [29] (Table 1). A standard calibration curve of Budesonide was prepared by recording the absorbance of various dilutions of the drug $(1.44,2.88$, $4.32,5.76,7.20,8.64$, and $10.08 \mu \mathrm{g} / \mathrm{mL}$ ) at $247 \mathrm{~nm}$ (JASCO V-630 spectrophotometer). Assay of the film formulations was estimated by placing a preweighed piece of film in a volumetric flask. Sufficient methanol was added and the flask was shaken for $24 \mathrm{~h}$ at laboratory ambient condition in an Orbital shaker (Remi Elektrotechnik Ltd, Vasai, India). Volume was made up to the $100 \mathrm{~mL}$ mark for the complete solubilization of film with methanol. The resulting solution was filtered (Whatman Uniflo $0.45 \mu \mathrm{m}, \mathrm{PVDF})$ and a serial dilution was made with aqueous phosphate buffer $(p \mathrm{H} 6.8)$ and checked spectrophotometrically at $247 \mathrm{~nm}$ [30,31]. Film thickness was measured 5-10 random portions by Mitutoyo Digimatic Micrometer (Japan) and the average values were recorded. Folding endurance of the film was observed by repeatedly folding a small strip of $2 \mathrm{~cm} \times 2 \mathrm{~cm}$ till it breaks. The number of times the film folded was measured as the folding endurance value.

Table 1. HPMC hydrogel film formulation of budesonide-cyclodextrin containing quaternary surfactant $^{\mathrm{a}}$

\begin{tabular}{|c|c|c|c|c|}
\hline Formulation code & $\begin{array}{l}\text { HPMC k15M } \\
\text { (mg) }\end{array}$ & $\begin{array}{c}\text { Surfactant } \\
(0.1 \%)\end{array}$ & $\begin{array}{l}\text { Inclusion agent } \\
\text { (molar ratio 1:1) }\end{array}$ & \begin{tabular}{l}
\multicolumn{1}{c}{ Budesonide } \\
Assay mean \pm sd \\
$(\%)$
\end{tabular} \\
\hline BHT & 900 & - & - & $3.78 \pm 0.194$ \\
\hline $\mathrm{BHT}_{\mathrm{b}} \mathrm{C}_{1}$ & 900 & BZK & $\beta$ - cyclodextrin & $2.48 \pm 0.065$ \\
\hline $\mathrm{BHT}_{\mathrm{b}} \mathrm{C}_{2}$ & 900 & $\mathrm{BZK}$ & HP- $\beta$-cyclodextrin & $2.55 \pm 0.03$ \\
\hline $\mathrm{BHT}_{\mathrm{c}} \mathrm{C}_{1}$ & 900 & CET & $\beta-$ cyclodextrin & $2.66 \pm 0.03$ \\
\hline $\mathrm{BHT}_{\mathrm{c}} \mathrm{C}_{2}$ & 900 & CET & HP- $\beta$-cyclodextrin & $2.49 \pm 0.05$ \\
\hline
\end{tabular}

\subsection{Moisture content and Moisture uptake}

Prepared films were cut into small pieces and put into the desiccator containing activated silica gel at least for $24 \mathrm{~h}$. The percentage of weight difference value of the films with respect to the initial was estimated as moisture content (\%). For evaluation of moisture uptake film pieces were placed for equilibration in a closed desiccator containing the supersaturated solution of sodium chloride for maintaining $75 \% \mathrm{RH}$ up to a constant weight. The weight difference value between final weight and initial weight was used $\%$ of moisture uptake of the films [32].

$$
\begin{gathered}
\text { Moisture Content }=\frac{(\text { Initial weight }- \text { dryweight after } 24 h)}{\text { Initial weight }} \times 100 \\
\text { Moisture Uptake }=\frac{(\text { Final weight }- \text { Initial weight before putting in dessicator })}{\text { Initial weight }} \times 100
\end{gathered}
$$

\subsection{Swelling and erosion study}

Dynamic hydration of swelling and erosion of the film was determined from the percentage hydration and matrix erosion using the following equations. Randomly selected film sample $(\approx 1 \mathrm{~cm} \times$ $1 \mathrm{~cm}$ ) was placed in Petri dishes containing $40 \mathrm{ml}$ of simulated buccal fluid (phosphate buffer of $\mathrm{pH}$ 6.8) [33]. The weight gained by the films was noted at regular intervals after removing excess liquid by tissue paper swabbing [34].

$$
\begin{aligned}
& \text { Dynamic hydration }=\frac{(\text { Hydrated weight }- \text { Initial dry weight of the film })}{\text { Weight after hydration }} \times 100 \\
& \text { Matrix erosion }=\frac{(\text { Initial dryweight }- \text { Dried final weight after swelling })}{\text { Initial dryweight }} \times 100
\end{aligned}
$$




\subsection{FTIR}

FTIR study was done for the prepared films and pure budesonide to observe drug-excipient interactions. Samples were placed on the diamond ATR crystal (JASCO ATR PRO ONE) in the FTIR spectrometer (JASCO FT/IR 4600). All the scans were done between $4000-400 \mathrm{~cm}^{-1}$ and an average of 80 scan accumulations at a resolution of $4 \mathrm{~cm}^{-1}$ were recorded.

\subsection{DSC (thermal analysis)}

Calorimetric study of budesonide and the formulations were performed by differential scanning calorimetry (Model: DSC-1, Mettler Toledo; Switzerland). The study was conducted at a temperature range of $30-300{ }^{\circ} \mathrm{C}$ under constant nitrogen flow $\left(20.0 \mathrm{~mL} \cdot \mathrm{min}^{-1}\right)$ and a heating rate of $+10^{\circ} \mathrm{C} \cdot \mathrm{min}^{-1}$.

\subsection{X-ray diffractometry}

X-ray diffraction pattern of pure budesonide and formulations were acquired by using X-ray diffractometry (Model: Rigaku Ultima IV). The voltage and current were $40 \mathrm{kV}$ and $15 \mathrm{~mA}$ respectively. The X-ray source anode material used was CU. $1 \%$ min scan speed was maintained and $\mathrm{X}$-axis values ranging between $5-70^{\circ} \mathrm{C}$ specifications test was carried out.

\subsection{SEM analysis}

Surface morphology of budesonide and the films were examined by scanning electron microscopy (Model: JEOL JSM-6510). Sputter coating with platinum was applied as a prior treatment before subjecting the samples in the SEM. Samples were scanned under an accelerated voltage of $30 \mathrm{kv}$ at room temperature. The film surfaces and crystal size of pure drug visualizing at 3,000-10,000X magnification.

\subsection{In-vitro drug release study}

Prepared budesonide films were attached on the surface of a glass slide with cyanoacrylate adhesive and fully merged it into the dissolution vessel containing $200 \mathrm{~mL}$ phosphate buffer $(6.8 \mathrm{pH})$ in a USP Type-II dissolution apparatus (Dissolution Tester USP, Electrolab TDT06L, India). The paddle was adjusted to $50 \mathrm{rpm}$ along with the temperature at $32 \pm 2{ }^{\circ} \mathrm{C}$ and the study was carried out for $6 \mathrm{~h} \mathrm{[35].} \mathrm{The} \mathrm{release} \mathrm{of} \mathrm{the} \mathrm{drug} \mathrm{was} \mathrm{estimated} \mathrm{spectrophotometrically.}$

\subsection{Mucosal permeation study}

Fresh buccal skins were collected from local chicken meat shop within an hour of its sacrifice. Buccal mucosal membranes were made free from fat and then washed with distilled water and dipped into phosphate buffer $p \mathrm{H} 6.8$ at room temperature. The dissected tissue was then attached to the diffusion tube in modified Franz diffusion cell. Buccal permeation was carried out for $6 \mathrm{~h}$ using phosphate buffer $6.8,200 \mathrm{~mL}$ as the diffusion media maintaining $34 \pm 0.2^{\circ} \mathrm{C}$. The samples were withdrawn at particular time intervals and assayed by UV Spectrophotometer to calculate the percentage of drug permeated [36].

\subsection{Anti-inflammatory activity study}

For in vivo anti-inflammatory study the ocular environment was much convenient because of its easy access and for the fact that mucin is present in both buccal and ocular environment [33]. New Zealand white rabbits of $1.5-2 \mathrm{Kg}$ were used for the study. Animals were held for $24 \mathrm{~h}$ in the laboratory before the experiment for environmental adaptation. This anti-inflammatory study was properly assessed and approved by the animal ethical committee of Siksha O Anusandhan (Deemed to be University) (IAEC no. IAEC/SPS/SOA/07/2019). Local ocular anesthesia was given with $0.5 \%$ Proparacaine $\mathrm{HCl}$ (Ophthalmic Solution) USP. Carrageenan $(200 \mu \mathrm{L}, 3 \% \mathrm{w} / \mathrm{v})$ was injected in the upper palpebral region of the eye of the rabbit by BD U-40 syringe to induce acute inflammation. The film $\left(\mathrm{BHT}_{\mathrm{b}} \mathrm{C}_{2}\right)$ was sterilized under UV radiation by keeping it for $10 \mathrm{mins}$ at a distance of $25 \mathrm{~cm}$ from 
the UV source. The sterilized film then placed at the cul-de-sac and ocular anti-inflammatory activity was visualized and photographed.

\section{Results and discussions}

\subsection{Physical characterization}

The average thickness of the films was found in the range of 160-195 $\mu \mathrm{m}$, well acceptable for mucosal application [37]. Films were showing good folding-endurance between 192-210 indicating sturdy and plasticized enough and not fragile due to the presence of triethanolamine [38]. The content of moisture in the films was found to be in the range of $1.25-2.41 \%$ in laboratory conditions.

The main role of moisture content in a film is to deliver enough plasticity and keeping it from being brittle. But excess moisture content affects the properties of the films. Moisture uptake study of the films was carried out at 75\% RH condition showed in the range of $5.59-5.69 \%$ [39]. The physical properties of the films are illustrated in Table 2.

Table 2. Physical properties of polymeric film

\begin{tabular}{|c|c|c|c|c|}
\hline $\begin{array}{l}\text { Formulation } \\
\text { Code }\end{array}$ & $\begin{array}{c}\text { Moisture } \\
\text { uptake } \\
\text { Mean } \pm \text { sd, } \\
(\mathrm{n}=4)(\%)\end{array}$ & $\begin{array}{c}\text { Moisture } \\
\text { content } \\
\text { Mean } \pm \text { sd, } \\
(n=4)(\%)\end{array}$ & $\begin{array}{c}\text { Thickness } \\
(\mu \mathrm{m}) \underset{(n=4)}{M} \pm \text {, } \\
(n=a n d\end{array}$ & $\begin{array}{c}\text { Folding } \\
\text { endurance }\end{array}$ \\
\hline BHT & $5.67 \pm 0.26$ & $2.41 \pm 0.66$ & $166.0 \pm 3.3$ & 192 \\
\hline $\mathrm{BHT}_{\mathrm{b}} \mathrm{C}_{1}$ & $5.59 \pm 0.40$ & $1.25 \pm 0.63$ & $178.1 \pm 7.5$ & 203 \\
\hline $\mathrm{BHT}_{\mathrm{b}} \mathrm{C}_{2}$ & $5.69 \pm 0.30$ & $1.70 \pm 0.44$ & $196.6 \pm 7.7$ & 209 \\
\hline $\mathrm{BHT}_{\mathrm{c}} \mathrm{C}_{1}$ & $5.64 \pm 0.36$ & $1.67 \pm 0.48$ & $174.6 \pm 4.9$ & 196 \\
\hline $\mathrm{BHT}_{\mathrm{c}} \mathrm{C}_{2}$ & $5.67 \pm 0.377$ & $2.12 \pm 0.37$ & $196.0 \pm 8.0$ & 201 \\
\hline
\end{tabular}

\subsection{Swelling and erosion study}

The swelling profile of the films was depicted in Figure 1. Hydration of water in the polymeric matrix was seen followed by matrix erosion. Rate of swelling increased significantly in the presence of cyclodextrin compared to its absence in the films. BHT showed swelling rate up to $2.402 \mathrm{~min}^{-1}$ whereas the film containing inclusion agent $\left(\mathrm{BHT}_{\mathrm{b}} \mathrm{C}_{1}, \mathrm{BHT}_{\mathrm{b}} \mathrm{C}_{2}, \mathrm{BHT}_{\mathrm{c}} \mathrm{C}_{1}\right.$, and $\left.\mathrm{BHT}_{\mathrm{c}} \mathrm{C}_{2}\right)$ showed 3.543, $3.656,3.624,3.134 \mathrm{~min}^{-1}$ (Table 3). Cyclodextrin in the polymeric film played a vital role in hydration to loosen the polymer network and increased water retention capacity $[40,41]$.

Table 3. Swelling behaviour and permeability parameter of budesonide film

\begin{tabular}{|c|c|c|c|c|}
\hline $\begin{array}{l}\text { Formulatio } \\
\text { n Code }\end{array}$ & $\begin{array}{c}\text { Rate of } \\
\text { Swelling }\left(K_{s}\right) \\
\left(\text { min }^{-1}\right)(\operatorname{mean} \pm \text { sd } \\
n=4)\end{array}$ & 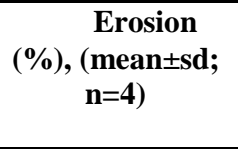 & $\begin{array}{c}\text { Flux }\left(J_{s}\right) \\
(\mu g / m i n) \\
(m e a n \pm s d ; \\
n=4)\end{array}$ & $\begin{array}{c}\text { Permeability } \\
\text { co-efficient }\left(\mathbf{P}_{\text {ss }}\right) \\
(\mathrm{cm} / \mathrm{min}) * 10^{5} \\
(\mathbf{m e a n} \pm \mathrm{sd} ; \mathrm{n}=4)\end{array}$ \\
\hline BHT & $2.4 \pm 0.4$ & $72.16 \pm 2.8$ & $0.82 \pm 0.15$ & $1.6 \pm 0.57$ \\
\hline $\mathrm{BHT}_{\mathrm{b}} \mathrm{C}_{1}$ & $3.5 \pm 0.3$ & $72.65 \pm 12$ & $1.41 \pm 0.47$ & $4.7 \pm 1.4$ \\
\hline $\mathrm{BHT}_{\mathrm{b}} \mathrm{C}_{2}$ & $3.6 \pm 0.1$ & $72.39 \pm 2.3$ & $1.67 \pm 0.74$ & $8.3 \pm 3.7$ \\
\hline $\mathrm{BHT}_{\mathrm{c}} \mathrm{C}_{1}$ & $3.6 \pm 0.3$ & $79.01 \pm 3.5$ & $2.12 \pm 0.49$ & $6.5 \pm 2.0$ \\
\hline $\mathrm{BHT}_{\mathrm{c}} \mathrm{C}_{2}$ & $3.1 \pm 0.1$ & $77.80 \pm 1.3$ & $1.44 \pm 0.21$ & $4.8 \pm 1.6$ \\
\hline
\end{tabular}




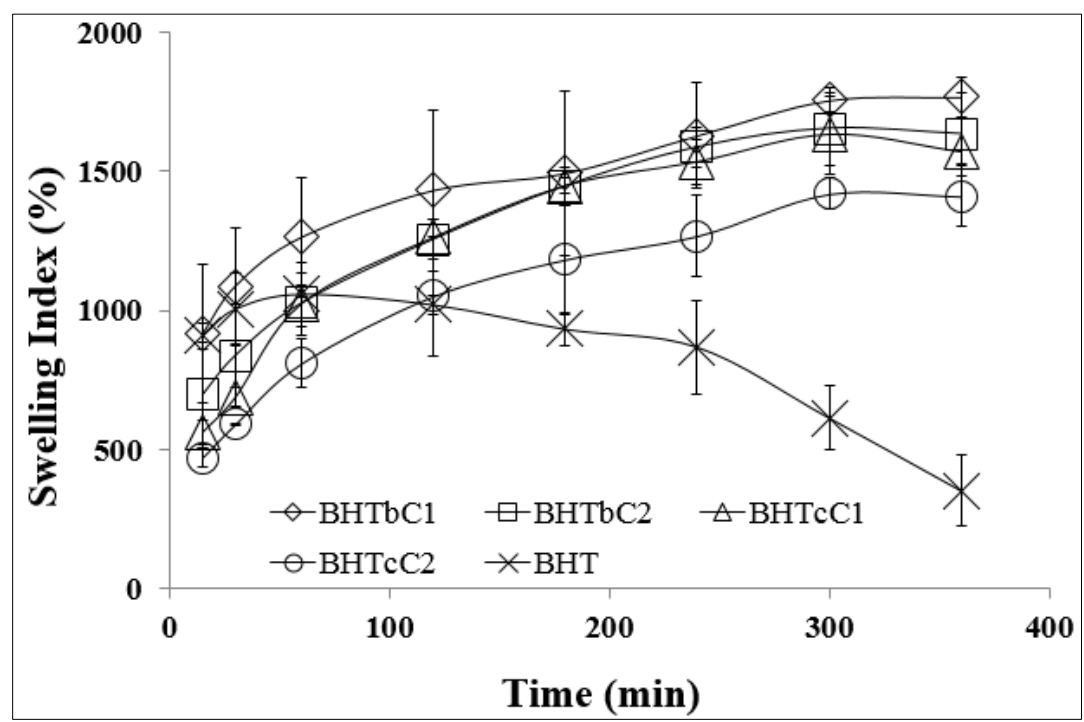

Figure 1. Swelling index profile of budesonide film

\subsection{FTIR study}

Polymer and drug intermolecular interactions were analyzed by the FTIR spectra (Figure 2A). Characteristic peaks of budesonide were showed at 3490, 2956, 1723, 1666, and $888 \mathrm{~cm}^{-1}$ due to the stretching of $\mathrm{O}-\mathrm{H}, \mathrm{C}-\mathrm{H}, \mathrm{C}=\mathrm{O}$, and $\mathrm{C}=\mathrm{C}[42,43]$. In the formulated films the peaks are masked, the characteristic $\mathrm{C}=\mathrm{O}$ stretching peak at 1666 shifted to 1656 with a decreased intensity. Broadening of the peaks at 1200-1000 regions was found. Masking, shifting and broadening of the parent peak intensity are the clear evidence of interaction of drug with polymers and cyclodextrins due to H-bond formation [30].

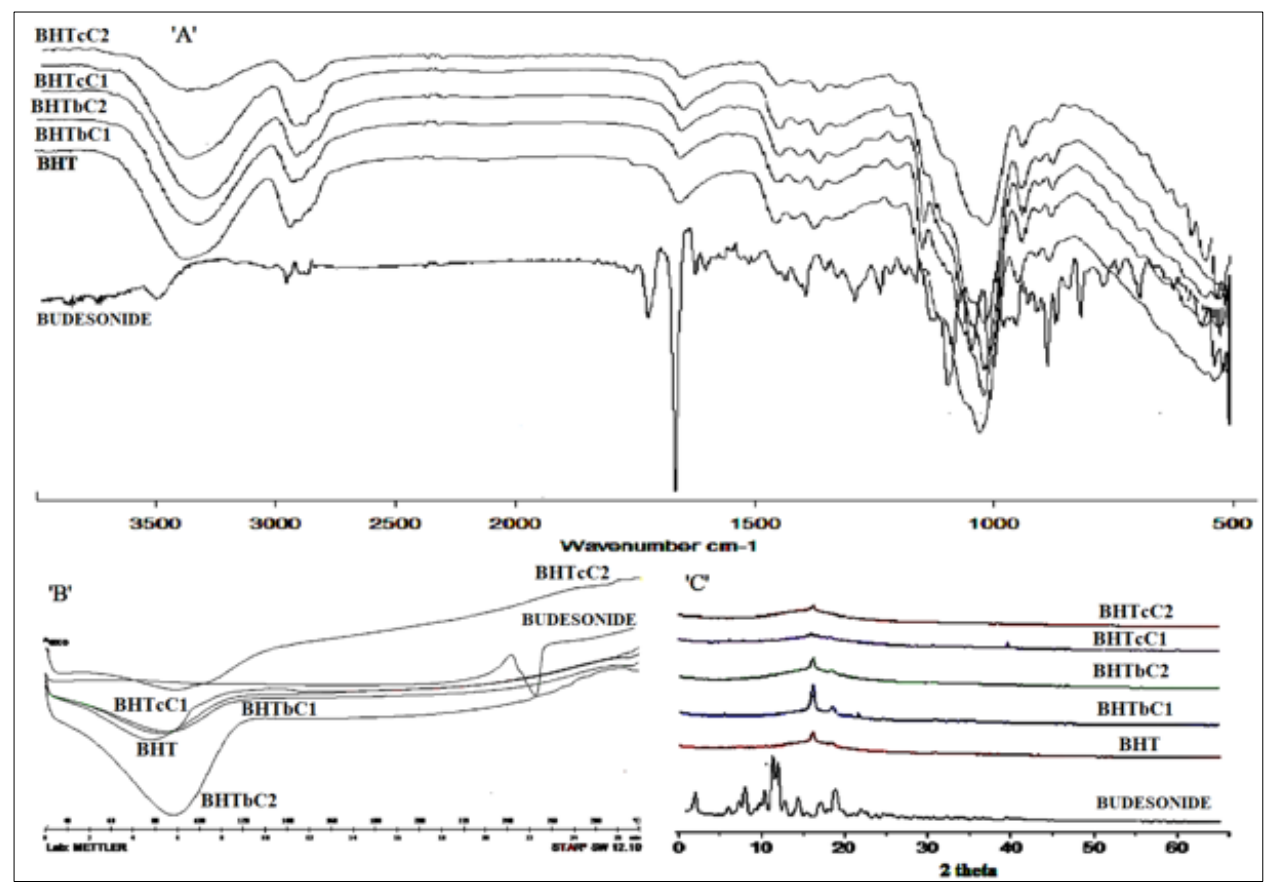

Figure 2. (A) FTIR study (B) DSC study (C) XRD study of pure drug and films

\subsection{DSC study}

DSC study was carried out to find the endothermic peak, crystalline behavior, and degradation of pure drug. Budesonide showed (Figure 2B) the sharp endothermic peak at $252.57^{\circ} \mathrm{C}$ due to the melting point of the drug. Polymeric films showed only a wide endothermic shouldering within $50-100^{\circ} \mathrm{C}$ 
specifying water evaporation of water from the hydrogel matrix. Complete disappearance of the melting peak demonstrated complete dispersion of budesonide in the polymer matrix and almost complete amorphization [44].

\subsection{XRD analysis}

X-ray diffractogram of pure budesonide (Figure 2C) showed high-intensity peaks at 6.21, 10.18, $11.49,12.17,15.53,16.10,22.162 \theta$ which can only be observed if the drug is in crystalline form [42]. The disappearance of the diffraction peaks in the polymeric matrix indicated intermolecular complexation between drug and polymer and almost complete amorphization of the drug crystal.

\subsection{SEM analysis}

Figure 3 depicts the SEM images of pure budesonide as regular geometric crystal form [45] and loss of geometry were clearly observed in the formulated polymeric films. All the film formulations showed smooth and homogenous surfaces may be due to interpenetration and considerable solubility of budesonide into the matrix system. The crystal grains are not visible even after $\times 10000$ magnification of the micrographs which confirms the lowering of crystalline intensity to a great extent. XRD and DSC report also confirmed the diminished crystallization of drug markedly in the polymeric film. Presence of HPMC arrested the crystal growth significantly in the film [38].
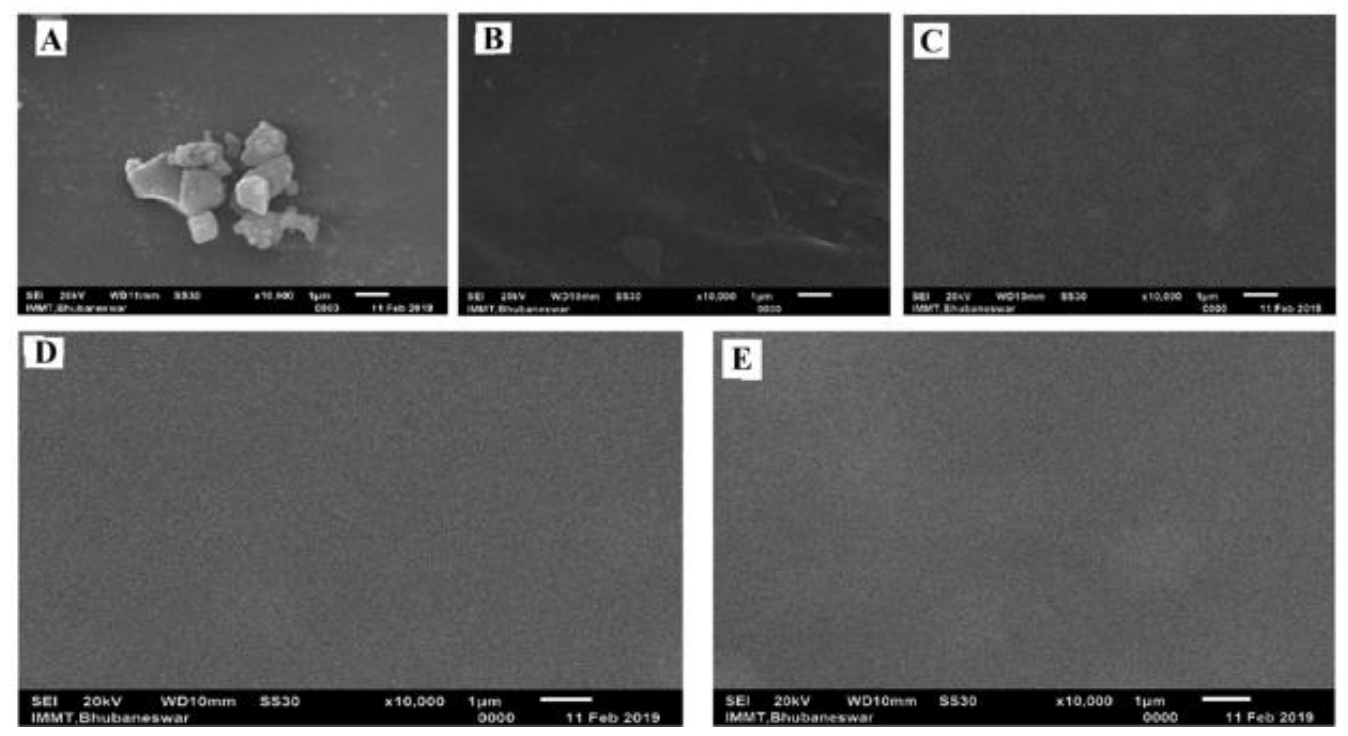

Figure 3. SEM images (A) Budesonide, (B) $\mathrm{BHT}_{b} \mathrm{C}_{1},(\mathrm{C}) \mathrm{BHT}_{\mathrm{b}} \mathrm{C}_{2},(\mathrm{D}) \mathrm{BHT}_{\mathrm{c}} \mathrm{C}_{1},(\mathrm{E}) \mathrm{BHT}_{\mathrm{c}} \mathrm{C}_{2}$

\subsection{In-vitro dissolution study}

Improved in-vitro cumulative drug release profiles have been observed from all the film formulations for an extended period of $6 \mathrm{~h}$ in Figure 4A. Drug release has been more effective due to the presence of inclusion agents and quaternary surfactants [46]. BHT formulation showed a release up to $63 \%$ whereas, the combination of cyclodextrin ( $\beta$-cyclodextrin or, HP- $\beta$-cyclodextrin) as an inclusion agent and surfactant (cetrimide or, benzalkonium chloride) improved the dissolution of the drug (77.8 to 87.2\%). $\mathrm{BHT}_{\mathrm{b}} \mathrm{C}_{2}$ formulation exhibited the in vitro release to the highest extent (87.2\%) due to the presence of benzalkonium chloride and HP- $\beta$-cyclodextrin compared to other formulations $\left(\mathrm{BHT}_{\mathrm{b}} \mathrm{C}_{1}: 84.12 ; \mathrm{BHT}_{\mathrm{c}} \mathrm{C}_{1}: 77.8\right.$; and $\left.\mathrm{BHT}_{\mathrm{c}} \mathrm{C}_{2}: 80.2 \%\right)$. In a literature report, it was noticed that the rate and extent of budesonide dissolution have become significantly effective by the use of lung surfactant [47]. Akkari et al 2016 have claimed that the addition of HP- $\beta$-cyclodextrin in the hydrogel matrix has increased the solubility of budesonide [48]. Lansoprazole dissolution was increased by the addition of cyclodextrin [19]. In a study presence of cetrimide or cyclodextrin has improved the solubility of valdecoxib [20]. Sodium lauryl sulphate $(0.5 \%)$ was used for maintaining sink condition in dissolution 
testing of a hydrogel containing budesonide tablet at $p \mathrm{H} 6.8$ [48]. Solubility of the budesonidecyclodextrin complex has further been improved in the presence of quaternary surfactants during the in vitro release study of the present film formulation. The difference and similarity factor $\left(f_{1}\right.$ and $\left.f_{2}\right)$ of the formulations (against BHT) has been tabulated (Table 4).

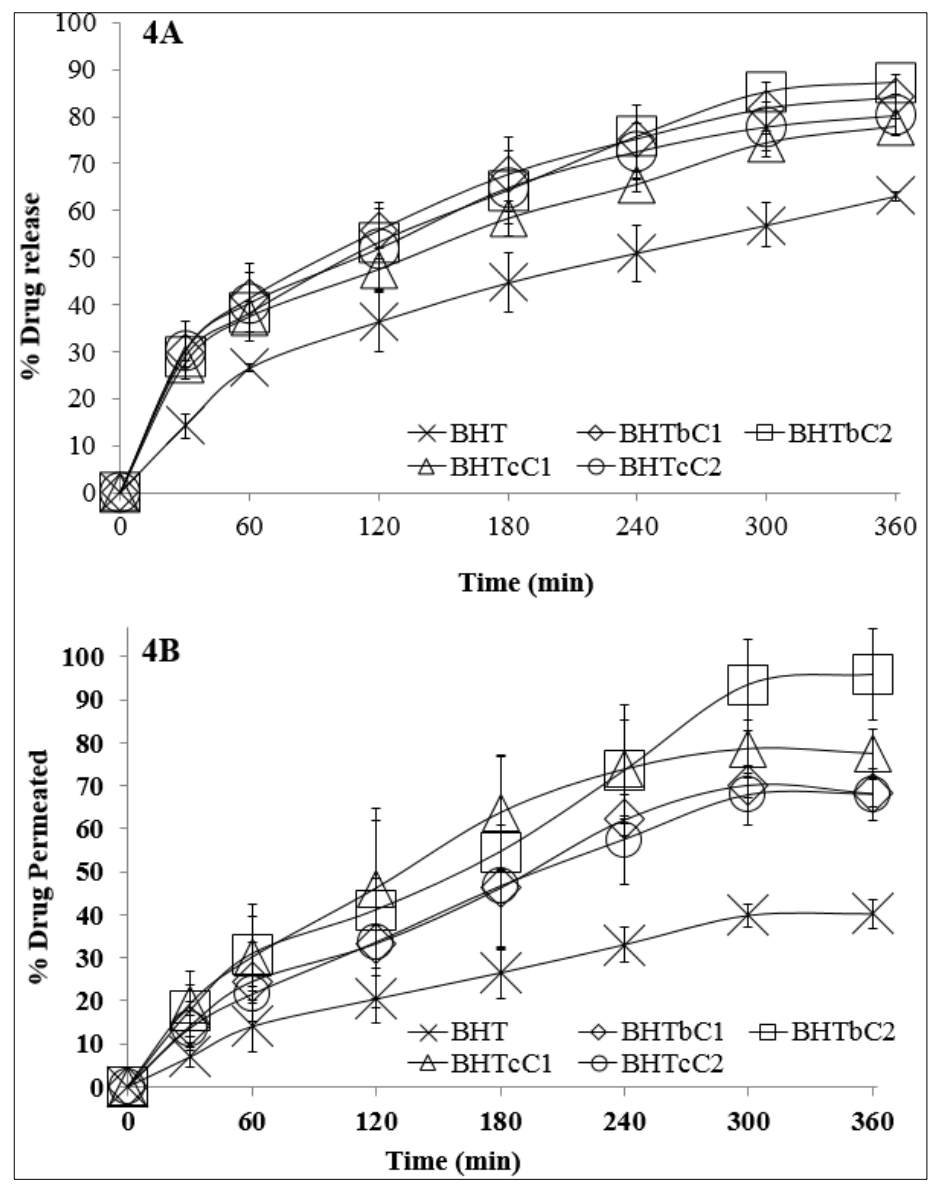

Figure 4. (A) In-vitro dissolution study (B) Buccal permeation study

Table 4. Comparison of in-vitro dissolution and mucosal permeation profiles

\begin{tabular}{|c|c|c|c|c|c|}
\hline \multirow{2}{*}{$\begin{array}{l}\text { Comparison } \\
\text { BHT }\end{array}$} & \multicolumn{2}{|c|}{ in-vitro dissolution } & \multicolumn{2}{|c|}{ mucosal permeation } & \multirow{2}{*}{$\begin{array}{l}\text { Similarity or } \\
\text { equivalence } \\
\text { value }\end{array}$} \\
\hline & $\begin{array}{r}\text { Differen } \\
\text { ce factor }\left(f_{1}\right)\end{array}$ & $\begin{array}{c}\text { Similarit } \\
\text { y factor }\left(f_{2}\right)\end{array}$ & $\begin{array}{l}\text { Difference } \\
\text { factor }\left(f_{l}\right)\end{array}$ & $\begin{array}{r}\text { Similarit } \\
\text { y factor }\left(f_{2}\right)\end{array}$ & \\
\hline BHT vs. $\mathrm{BHT}_{\mathrm{b}} \mathrm{C}_{1}$ & 49.054 & 34.024 & 76.176 & 33.234 & \multirow{2}{*}{$f_{1} \leq 15$} \\
\hline BHT vs. $\mathrm{BHT}_{\mathrm{b}} \mathrm{C}_{2}$ & 47.911 & 34.079 & 125.124 & 21.981 & \\
\hline BHT vs. $\mathrm{BHT}_{\mathrm{c}} \mathrm{C}_{1}$ & 32.651 & 42.932 & 114.997 & 24.985 & \multirow[t]{2}{*}{$f_{2} \geq 50$} \\
\hline BHT vs. $\mathrm{BHT}_{\mathrm{c}} \mathrm{C}_{2}$ & 42.847 & 37.046 & 70.520 & 34.805 & \\
\hline
\end{tabular}

\subsection{Mucosal permeation study}

Mucosal permeation was carried out also for $6 \mathrm{~h}$ by using chicken buccal tissue as a mucosal membrane (Figure 4B). Presence of inclusion agent ( $\beta$-cyclodextrin or, HP- $\beta$-cyclodextrin) and surfactant (cetrimide or, benzalkonium chloride) significantly improved also the permeation $\left(\mathrm{BHT}_{\mathrm{b}} \mathrm{C}_{1}\right.$ : 70.1; $\mathrm{BHT}_{\mathrm{b}} \mathrm{C}_{2}: 95.8 ; \mathrm{BHT}_{\mathrm{c}} \mathrm{C}_{1}: 78.5$ and $\left.\mathrm{BHT}_{\mathrm{c}} \mathrm{C}_{2}: 67.9 \%\right)$ compared to its absence in the film (BHT: $40.2 \%)$. Among all the formulations, the benzalkonium chloride-containing film along with HP- $\beta$ cyclodextrin showed the highest result $\left(\mathrm{BHT}_{\mathrm{b}} \mathrm{C}_{2}: 95.8 \%\right)$. Benzalkonium chloride or cetrimide in the 
film $\left(\mathrm{BHT}_{\mathrm{b}} \mathrm{C}_{2}\right.$ and $\mathrm{BHT}_{\mathrm{c}} \mathrm{C}_{1}$ respectively) increased the release of drug on the mucosal surface because of its surfactant property and facilitated the better permeation via paracellular route compared to BHT [23]. Additionally, the cationic surfactants overcame the physiological and mucosal barrier for the increase of permeation and BZK exhibited better ability rather than CET [49]. Cyclodextrin exhibited increased transmucosal diffusion of omeprazole [21]. BZK was found to be facilitating the mucosal permeation of fluorescein isothiocyanate dextran [22]. $f_{1}$ and $f_{2}$ of the formulations with respect to BHT are tabulated in Table 4.

\subsection{Kinetics of drug release and permeation}

Korsmeyer-Peppas, Higuchi, and first-order model equations were used to describe the drug release and permeation kinetics of the drug [50,51]. The parameters were reported in Table 5.

Korsmeyer-Peppas:

Higuchi Kinetics:

$$
\frac{W_{t}}{W_{\infty}}=K_{k} t^{n}
$$

First-order:

$$
H=K_{h} \sqrt{t}
$$

$$
\log H=\log H_{0}+\frac{k t}{2.303}
$$

Here, $\mathrm{W}_{\mathrm{t}}$ is the fraction of drug released/permeated at time " $\mathrm{t}$ ", and $\mathrm{W}_{\infty}$ maximum amount of drug available at the release/permeation site, $\mathrm{K}_{\mathrm{k}}$ is the constant related to system structure and geometry and $n$ is the drug release exponent. $\mathrm{H}$ and $\mathrm{K}_{\mathrm{h}}$ signify the amount of drug released per unit area of the film and Higuchi rate constant for release/permeation respectively. The drug release of all the formulation could be described as a diffusion-controlled process $(n=0.40-0.56)$ [52].

$$
P_{S S}=\frac{J_{S S}}{C}
$$

$\mathrm{C}=$ drug concentration remaining in the formulation $(\mathrm{X} / \mathrm{V})[$ where $\mathrm{X}=$ cumulative drug amount in receiver compartment]

Jss $=$ Flux of permeation at steady state calculated from the slope of $X$ vs time plot.

The amount of drug permeated or permeability co-efficient ' $P_{s s}$ ' of $\mathrm{BHT}_{\mathrm{b}} \mathrm{C}_{2}$ film $\left(8.311^{*} 10^{-5}\right)$ was better than the other formulations demonstrated in Table 3 [53,54]. A low amount of drug was permeated from the BHT formulation $\left(1.675^{*} 10^{-5}\right)$. According to the Korsmeyer-Peppas equation, the ' $n$ ' value lies in between 0.59 to 0.7 indicating majorly diffusion-controlled and partially erosion controlled release (Table 5) [50]. The erosion of the film (BHT) was higher relative to other formulations $\left(\mathrm{BHT}_{\mathrm{b}} \mathrm{C}_{1}, \mathrm{BHT}_{\mathrm{b}} \mathrm{C}_{2}, \mathrm{BHT}_{\mathrm{c}} \mathrm{C}_{1}\right.$, and $\left.\mathrm{BHT}_{\mathrm{c}} \mathrm{C}_{2}\right)$. On the other hand, $\mathrm{BHT}_{\mathrm{c}} \mathrm{C}_{1}$ has shown

\begin{tabular}{|c|c|c|c|c|c|c|c|c|c|c|}
\hline \multirow{3}{*}{$\begin{array}{l}\text { Formulation } \\
\text { code }\end{array}$} & \multicolumn{5}{|c|}{ Release } & \multicolumn{5}{|c|}{ Permeation } \\
\hline & \multirow{2}{*}{$\begin{array}{c}\begin{array}{c}\text { First } \\
\text { order }\end{array} \\
\mathrm{r}^{2} \\
\end{array}$} & \multicolumn{2}{|c|}{ Higuchi } & \multicolumn{2}{|c|}{ Peppas } & \multirow{2}{*}{$\begin{array}{c}\text { First order } \\
r^{2}\end{array}$} & \multicolumn{2}{|c|}{ Higuchi } & \multicolumn{2}{|c|}{ Peppas } \\
\hline & & $\mathrm{k}$ & $\mathrm{r}^{2}$ & $\mathrm{n}$ & $\mathrm{r}^{2}$ & & $\mathrm{k}$ & $\mathrm{r}^{2}$ & $\mathrm{n}$ & $\mathrm{r}^{2}$ \\
\hline BHT & 0.978 & 3.372 & 0.995 & 0.569 & 0.981 & 0.976 & 2.295 & 0.980 & 0.71 & 0.986 \\
\hline $\mathrm{BHT}_{\mathrm{b}} \mathrm{C}_{1}$ & 0.980 & 4.503 & 0.988 & 0.425 & 0.995 & 0.964 & 3.996 & 0.970 & 0.68 & 0.985 \\
\hline $\mathrm{BHT}_{\mathrm{b}} \mathrm{C}_{2}$ & 0.988 & 4.699 & 0.996 & 0.463 & 0.996 & 0.966 & 5.307 & 0.960 & 0.69 & 0.984 \\
\hline $\mathrm{BHT}_{\mathrm{c}} \mathrm{C}_{1}$ & 0.977 & 4.06 & 0.994 & 0.422 & 0.997 & 0.957 & 4.55 & 0.978 & 0.55 & 0.982 \\
\hline $\mathrm{BHT}_{\mathrm{c}} \mathrm{C}_{2}$ & 0.970 & 4.262 & 0.986 & 0.406 & 0.995 & 0.984 & 3.919 & 0.978 & 0.69 & 0.995 \\
\hline
\end{tabular}
mostly diffusion-controlled compared to other films. The erosion of the films were in the order of: $\mathrm{BHT}>\mathrm{BHT}_{\mathrm{b}} \mathrm{C}_{2}, \mathrm{BHT}_{\mathrm{c}} \mathrm{C}_{2}>\mathrm{BHT}_{\mathrm{b}} \mathrm{C}_{1}>\mathrm{BHT}_{\mathrm{c}} \mathrm{C}_{1}$.

Table 5. Kinetic parameter of in-vitro drug release and ex-vivo buccal permeation 


\title{
3.10 Anti-inflammatory activity
}

Budesonide (1 mg equivalent) containing film formulation $(26.4-40.3 \mathrm{mg}$ ) has been used for antiinflammatory study after topical application. The probable methanol content in the film used for the anti-inflammatory study was well below the permissible daily exposure according to the European Medicines Agency - ICH guideline Q3C (R6) on impurities (30 mg/day). Carrageenan was found to be more convenient than the Freund's adjuvant for its chronic inflammation which can elongate up to 14 days but carrageenan causes an acute inflammation which gives effect up to $24 \mathrm{~h}$ [55]. After 30 minutes from the carrageenan injection (Figure 5A), frequent lacrimation, meibomian secretion, reddening, and swelling of the conjunctiva appeared in comparison to the normal eye (Figure 5B, 5C). But there were no signs and symptoms in the normal/control eye. (Figure 5E). The film, $\mathrm{BHT}_{\mathrm{b}} \mathrm{C}_{2}$ has exhibited the highest extent of in-vitro dissolution and also ex vivo mucosal permeation and selected for in vivo anti-inflammatory activity study. After complete inflammation, the film $\left(\mathrm{BHT}_{\mathrm{b}} \mathrm{C}_{2}\right)$ was placed in the cul-de-sac region of the rabbit eye. The symptoms of inflammation like redness were decreased within 3 hours after the film was applied. But inflammation was not decreased in the positive controlled eye and redness not decreased within the $3 \mathrm{~h}$ (Figure 5F) [32,56].

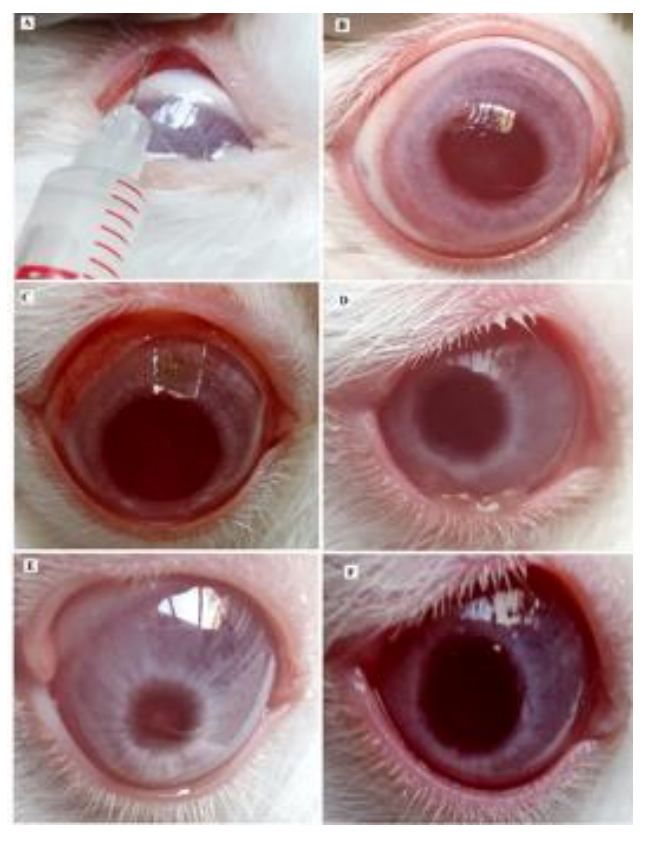

\author{
Figure 5. (A) Injecting carrageenan in \\ the upper palpebral region; (B) Normal \\ rabbit eye (right) before carrageenan \\ injection; (C) Acute inflammation in the \\ rabbit eye (right) $30 \mathrm{~min}$ after \\ carrageenan injection; (D) Inflammation \\ of the eye (right) significantly reduced \\ after application of film formulation \\ $\left(\mathrm{BHT}_{\mathrm{b}} \mathrm{C}_{2}\right)(\mathrm{E})$ Rabbit normal eye (left) \\ without carrageenan injection and \\ without application of film; (F) Acute \\ inflammation in the rabbit eye (right) \\ after $3 \mathrm{~h}$ of carrageenan injection without \\ film application.
}

\section{Conclusions}

Hydrogel forming film formulation has been prepared with cyclodextrin complexation of budesonide containing quaternary surfactant and in vitro-in vivo assessment of mucosal drug delivery was carried out. Inclusion agents in the film increased the drug release and swelling rate. The erosion rate of the hydrogel film has been decreased in presence of inclusion agent. Enhanced mucosal permeation was also observed due to the increased release of drug on the mucosal surface and the surfactant property of the quaternary compounds which facilitated better permeation probably via paracellular route compared to others. A majorly diffusion-controlled mechanism was observed in the process of drug release and mucosal transport with minimal erosion. Budesonide hydrogel has finally shown ocular anti-inflammatory activity after topical application in vivo. Inflammatory conditions have believably been encountered after reaching of budesonide to the target site bypassing the firstpass metabolism and could be the cause of improved bioavailability.

Acknowledgement. The authors are thankful to Prof. Manoj Ranjan Nayak, President of Siksha 'O' Anusandhan (Deemed to be University) for providing the facilities required for successful completion of the work. 


\section{References}

1.VARSHOSAZ, J., EMAMI, J., AHMADI, F., TAVAKOLI, N., MINAIYAN, M., FASSIHI, A., MAHZOUNI, P., DORKOOSH, F., Preparation of budesonide-dextran conjugates using glutarate spacer as a colon-targeted drug delivery system: in vitro/in vivo evaluation in induced ulcerative colitis. J Drug Target. 19(2), 2011, p. 140-53.

2.SZEFLER, S.J., Pharmacodynamics and pharmacokinetics of budesonide: a new nebulized corticosteroid. J. Allergy Clin. Immunol., 104(4), 1999, p. S175-83.

3.BEGAT, P., MORTON, D.A., STANIFORTH, J.N., PRICE, R., The cohesive-adhesive balances in dry powder inhaler formulations II: influence on fine particle delivery characteristics. Pharm. Res., 21(10) 2004, p. 1826-33.

4.HASSAN, N., AHAD, A., ALI, M., ALI, J., Chemical permeation enhancers for transbuccal drug delivery. Expert Opin Drug Deliv., 7(1), 2010, p. 97-112.

5.SMART, J.D., Buccal drug delivery. Expert Opin. Drug Deliv., 2(3), 2005, p. 507-17

6.LAQUINTANA, V., ASIM, M.H., LOPEDOTA, A., CUTRIGNELli, A., LOPALCO, A., FRANCO, M., BERNKOP-SCHNÜRCH, A., DENORA, N., Thiolated hydroxypropyl- $\beta$-cyclodextrin as mucoadhesive excipient for oral delivery of budesonide in liquid paediatric formulation. Int $\mathbf{J}$ Pharm., 572, 2019, p. 118820.

7.NAKAMURA, K., MAITANI, Y., LOWMAN, A.M., TAKAYAMA, K., PEPPAS, N.A., NAGAI, T., Uptake and release of budesonide from mucoadhesive, $\mathrm{pH}$-sensitive copolymers and their application to nasal delivery. J. Control. Release., 61(3), 1999, p. 329-35.

8.MUT, A.M., VLAIA, L., CONEAC, G., OLARIU, I.O., VLAIA, V.I., POPOIU, C.Ă., HÎRJĂU, M.I., LUPULIASA, D.U., Novel Topical Chitosan/Hydroxypropyl methylcellulose-Based Hydrogels Containing Fluconazole and Sucrose Esters. Formulation, Physicochemical Characterization. In vitro Drug Release and Permeation. Farmacia., 66, 2018, p. 59-69.

9.PANAINTE, A.D., POPA, G., PAMFIL, D., BUTNARU, E., VASIle, C., TARȚĂU, L.M., GAFIT,ANU, C., In vitro characterization of polyvinyl alcohol/chitosan hydrogels as modified release systems for bisoprolol. Farmacia. 66(1), 2018, p. 144-8.

10.ESIM, O., SAVASER, A., OZKAN, C.K., BAYRAK, Z., TAS, C., OZKAN, Y., Effect of polymer type on characteristics of buccal tablets using factorial design. Saudi Pharm. J., 26(1), 2018, p. 53-63.

11.AL-DHUBIAB, B.E., NAIR, AB, KUMRIA, R, ATTIMARAD, M, HARSHA, S. Development and evaluation of nebivolol hydrochloride nanocrystals impregnated buccal film. Farmacia., 67, 2017, p. 282-289.

12.SALAMAT-MILlER, N., CHITTCHANG, M., JOHNSTON, T.P., The use of mucoadhesive polymers in buccal drug delivery. Adv. Drug Deliv. Rev., 57(11), 2005, p. 1666-91.

13.GAIKWAD, N.M., SHAIKH, K.S., CHAUDHARI, P.D., Development and Evaluation of a System for Colonic Delivery of Budesonide. Indian J Pharm Educ Res., 51(4), 2017, p. 551-61.

14.KUMAR, M., PATHAK, K., MISRA, A., Formulation and characterization of nanoemulsion-based drug delivery system of risperidone. Drug Dev Ind Pharm., 35(4), 2009, p. 387-95.

15.BANDI, N., WEI, W., ROBERTS, C.B., KOTRA, L.P., KOMPELLA, U.B., Preparation of budesonide and indomethacin hydroxypropyl- $\beta$-cyclodextrin (HPBCD) complexes using a single-step, organic-solvent-free supercritical fluid process. Eur. J. Pharm. Sci., 23(2), 2004, p. 159-68.

16.ANTAL, D.S., ARDELEAN, F., PINZARU, I., BORCAN, F., LEDEŢI, I., CORICOVAC, D., ZUPKÓ, I., BAGHDIKIAN, B., OLLIVIER, E., SOICA, C., BOLINITINEANU, S.L., Effects of cyclodextrin complexation on the anti-cancer effects of Cotinus coggygria extract and its constituents, butein and sulfuretin., Rev. Chim., 67(8), 2016, 1618-22.

17.MARIAN, E., JURCA, T., VICAŞ, L., KACSO, I., MICLĂUŞ, M., BRATU, I., Inclusion compounds of erythromycin with $\beta$-cyclodextrin., Rev Chim., 62(11), 2011, 1065-8.

18.POPA, G., DRAGOSTIN, O., BUZIA, O.D., TARTAU, L.M., PROFIRE, L., GAFITANU, C., Studies on Obtaining and Characterization a Pregabalin-cyclodextrin Complex for Taste Masking Purpose., Rev Chim., 68, 2017, p. 337-80. 
19.LU, Y., GUO, T., QI, J., ZHANG, J., WU, W., Enhanced dissolution and stability of lansoprazole by cyclodextrin inclusion complexation: Preparation, characterization, and molecular modeling. AAPS PharmSciTech., 13(4), 2012, p. 1222-9.

20.MODI, A., TAYADE, P., A comparative solubility enhancement profile of valdecoxib with different solubilization approaches. Indian J. of Pharm. Sci., 69(2), 2007, p. 274.

21.FIGUEIRAS, A., HOMBACH, J., VEIGA, F., BERNKOP-SCHNÜRCH, A., In vitro evaluation of natural and methylated cyclodextrins as buccal permeation enhancing system for omeprazole delivery. Eur J Pharm Biopharm., 71(2), 2009, p. 339-45

22.SASAKI, H., YAMAMURA, K., TEI, C., NISHIDA, K., NAKAMURA, J., Ocular permeability of FITC-dextran with absorption promoter for ocular delivery of peptide drug. J Drug Target., 3(2), 1995, p. 129-35.

23.JIN, L., BOYD, B.J., WHITE, P.J., PENNINGTON, M.W., NORTON. R.S., NICOLAZZO, J.A., Buccal mucosal delivery of a potent peptide leads to therapeutically-relevant plasma concentrations for the treatment of autoimmune diseases. J Control Release., 199, 2015, p. 37-44.

24.VALENTE, A.J.M., SÖDERMAN, O., The formation of host-guest complexes between surfactants and cyclodextrins. Adv Colloid Interface Sci., 205, 2014, p. 156-76

25.JIANG, B.Y., DU, J., CHENG, S.Q., PAN, J.W., ZENG, X.C., LIU, Y.J., SHUNZO, Y., YOSHIMI, S., Effects of cyclodextrins as additives on surfactant CMC. J Dispers Sci Technol., 24(1), 2003, p. 63-6.

26.ŞENEL, S., RATHBONE, M.J., CANSIZ, M., PATHER, I., Recent developments in buccal and sublingual delivery systems. Expert Opin. Drug Deliv., 9(6), 2012, p. 615-28.

27.GUSTAFSSON, B., MILLER-LARSSON, A., PERSSON, C.G., Topical and oral antiinflammatory activity of budesonide compared with oral prednisolone in an animal model using allergen-induced gut mucosal exudation of plasma as a marker. Scand. J. Gastroenterol., 36(10), 2001, p. 1062-6.

28.MILLER-LARSSON, A., BRATTSAND, R., Topical anti-inflammatory activity of the glucocorticoid budesonide on airway mucosa. Evidence for a "hit and run" type of activity. Inflamm. Res., 29(1), 1990, p. 127-9.

29.MOHAPATRA, R., MALLICK, S., NANDA, A., SAHOO, R.N., PRAMANIK, A., BOSE, A., DAS, D., PATTNAIK, L., Analysis of steady state and non-steady state corneal permeation of diclofenac. RSC Adv., 6(38), 2016, p. 31976-87.

30.BHATT, H., NAIK, B., DHARAMSI, A., Solubility enhancement of budesonide and statistical optimization of coating variables for targeted drug delivery. J. Pharm., 2014, p. 1-13.

31.RAVAL, M.K., RAMANI, R.V., SHETH, N.R., Formulation and evaluation of sustained release enteric-coated pellets of budesonide for intestinal delivery. Int. J. Pharm Investigation., 3(4), 2013, p. 203-11.

32.NANDA, A., SAHOO, R.N., PRAMANIK, A., MOHAPATRA, R., PRADHAN, S.K., THIRUMURUGAN, A., DAS, D., MALLICK, S., Drug-in-mucoadhesive type film for ocular antiinflammatory potential of amlodipine: effect of sulphobutyl-ether-beta-cyclodextrin on permeation and molecular docking characterization. Colloids Surf. B., 172, 2018, p. 555-64.

33.PANDA, B., SUBHADARSINI, R., MALLICK, S., Biointerfacial phenomena of amlodipine buccomucosal tablets of HPMC matrix system containing polyacrylate polymer/ $\beta$-cyclodextrin: correlation of swelling and drug delivery performance. Expert Opin. Drug Deliv., 13(5), 2016, p. 63343.

34.SUJJA-AREEVATH, J., MUNDAY, D.L., COX, P.J., KHAN, K.A., Relationship between swelling, erosion and drug release in hydrophillic natural gum mini-matrix formulations. Eur. J. Pharm. Sci., 6(3), 1998, p. 207-17.

35.PRAMANIK, A., SAHOO, R.N., NANDA, A., MOHAPATRA, R., SINGH, R., MALLICK, S., Ocular Permeation and Sustained Anti-inflammatory Activity of Dexamethasone from Kaolin Nanodispersion Hydrogel System. Curr. Eye Res., 43(6), 2018, p. 828-38. 
36.ELKOMY, M.H., MENSHAWE, S.F., ABOU-TALEB, H.A., ELKARMALAWY, M.H., Loratadine bioavailability via buccal transferosomal gel: formulation, statistical optimization, in vitro/in vivo characterization, and pharmacokinetics in human volunteers. Drug Deliv., 24(1), 2017, p. 781-91.

37.SEMALTY, M., SEMALTY, A., KUMAR, G., Formulation and characterization of mucoadhesive buccal films of glipizide. Indian J. Pharm. Sci., 70(1), 2008, p. 43.

38.PANDA, B., PARIHAR, A.S., MALLICK, S., Effect of plasticizer on drug crystallinity of hydroxypropyl methylcellulose matrix film. International journal of biological macromolecules., 67, 2014, p. 295-302.

39.MOHAPATRA, R., SENAPATI, S., SAHOO C., MALLICK, S., Thermodynamic properties of ocular permeation of diclofenac: effect of triethanolamine. Farmacia., 64(1), 2016, p. 72-81.

40.FOLCH-CANO, C., YAZDANI-PEDRAM, M., OLEA-AZAR, C., Inclusion and functionalization of polymers with cyclodextrins: current applications and future prospects. Molecules., 19(9), 2014, p. 14066-79.

41.POSE-VILARNOVO, B., RODRÍGUEZ-TENREIRO, C., DOS SANTOS, J.F., VÁZQUEZDOVAL, J., CONCHEIRO, A., ALVAREZ-LORENZO, C., TORRES-LABANDEIRA, J.J., Modulating drug release with cyclodextrins in hydroxypropyl methylcellulose gels and tablets. J control release., 94(2-3), 2004, p. 351-63.

42.MALI, A.J., PAWAR, A.P., PUROHIT, R.N., Development of budesonide loaded biopolymer based dry powder inhaler: optimization, in vitro deposition, and cytotoxicity study. J. pharm., 2014, http://dx.doi.org/10.1155/2014/795371

43.CORTESI, R., RAVANI, L., MENEGATTI, E., ESPOSITO, E., RONCONI, F., Eudragit ${ }^{\circledR}$ microparticles for the release of budesonide: a comparative study. Indian J. pharm. sci., 74(5), 2012, p. 415-21.

44.VOZONE, C.M., MARQUES H.M., Complexation of budesonide in cyclodextrins and particle aerodynamic characterization of the complex solid form for dry powder inhalation. . J. Incl. Phenom. Macrocycl. Chem., 44(1-4), 2002, p. 111-6.

45.CARR, A.G., MAMMUCARI, R., FOSTER, N.R., Particle formation of budesonide from alcoholmodified subcritical water solutions. International journal of pharmaceutics., 405(1-2), 2011, p. 16980 .

46.LEUNER, C., DRESSMAN, J., Improving drug solubility for oral delivery using solid dispersions. Eur. J. Pharm. Biopharm., 50(1), 2000, p. 47-60.

47.PHAM, S., WIEDMANN, T.S., Note: Dissolution of aerosol particles of budesonide in Survanta ${ }^{\mathrm{TM}}$, a model lung surfactant. Journal of pharmaceutical sciences., 90(1), 2001, p. 98-104.

48.AKKARI, A.C., CAMPOS, E.V., KEPPLER, A.F., FRACETO, L.F., DE, PAULA, E., TOFOLI, G.R., DE ARAUJO D.R., Budesonide-hydroxypropyl- $\beta$-cyclodextrin inclusion complex in binary poloxamer 407/403 system for ulcerative colitis treatment: A physico-chemical study from micelles to hydrogels. Colloids and Surfaces B: Biointerfaces., 138, 2016, p. 138-47.

49.MOHAPATRA, R., SENAPATI, S., SAHOO, C., MALLICK, S., Transcorneal permeation of diclofenac as a function of temperature from film formulation in presence of triethanolamine and benzalkonium chloride. Colloids Surf. B., 123, 2014, p. 170-80.

50.RITGER, P.L., PEPPAS, N.A., A simple equation for description of solute release II. Fickian and anomalous release from swellable devices. J. Control. Release., 5(1), 1987, p. 37-42.

51.PATTNAIK, S., SWAIN, K., MALLICK, S., Influence of polymeric system and loading dose on drug release from alfuzosin hydrochloride transdermal films. Lat. Am. J. Pharm., 28(1), 2009, p. 62-9.

52.EL AFIF, A., GRMELA, M., Non-Fickian mass transport in polymers. J. Rheol., 46(3), 2002, p. 591-628.

53.UBAID, M., ILYAS, S., MIR, S., KHAN, A.K., RASHID, R., KHAN, M.Z., KANWAL, Z.G., NAWAZ, A., SHAH, A., MURTAZA, G., Formulation and in vitro evaluation of carbopol 934-based modified clotrimazole gel for topical application. An. Acad. Bras. Cienc., 88(4), 2016, p. 2303-17. 
54.SWAIN, K., PATTNAIK, S., SAHU, S.C., MALLICK, S., Feasibility assessment of ondansetron hydrochloride transdermal systems: physicochemical characterization and in vitro permeation studies. Lat Am J Pharm., 28(5), 2009, p. 706-14.

55.FEHRENBACHER, J.C., VASKO, M.R., DUARTE, D.B., Models of inflammation: carrageenan or complete freund's adjuvant (CFA) induced edema and hypersensitivity in the rat. Curr Protoc Pharmacol., 56(1), 2012, p. 5.4.1-5.4.7.

56.LIN, N., POPOVICH, T., THOMPSON, H., PALACIOSPELAEZ, R., BAZAN, N.G., Prolonged anti-inflammatory effect of Budesonide Epimer $\mathrm{R}$ in experimental uveitis. Invest Ophth Vis Sci., 37(3), 1996, p. 180

Manuscript received: 5.03.2020 